\title{
EFFECTS OF CYANIDE ON ORNAMENTAL CORAL FISH (CHROMIS VIRIDIS)
}

\author{
Z. Arifin and D. Hindarti \\ Ecotoxicology Working Group, Research Center for Oceanography, \\ Indonesian Institute of Sciences (LIPI) \\ Jl. Pasir Putih I, Jakarta 14430, Indonesia \\ e-mail: zarifin@oseanografi.1ipi.go.id
}

\begin{abstract}
The use of cyanide particularly for fishing has caused concern for its impacts on aquatic marine life. This study was the first attempt to provide information on the effect of cyanide on tropical marine fish in Indonesia and aimed to determine the toxicity of cyanide to coral fish, Chromis viridis. The fish were exposed to 10,18,32,56 and $100 \mu \mathrm{g} 1^{-1}$ of cyanide. These five cyanide concentrations were tested for 96$\mathrm{h}$ period of exposure through a static-renewal. Cyanide was found to be very toxic to the fish. The 96-h $\mathrm{LC}_{50}$ of cyanide for juvenile of Chromis viridis was $41.3 \mu \mathrm{g} 1^{-1}$. The toxicity of cyanide to C. viridis was 300 times stronger than that of the trace metal cadmium. Compared to milkfish fry (Chanos chanos), $C$. viridis was more sensitive to cyanide. It is estimated that at concentration of $32 \mu \mathrm{g} 1^{-1}$ cyanide does not show observable effect (NOEC) to $C$. viridis. Meanwhile the lowest observable effect of cyanide (LOEC) to the fish is at a concentration of $56 \mu \mathrm{g} 1^{-1}$.
\end{abstract}

Keywords: Chromis viridis, coral fish, cyanides, lethal dose, toxicity

\section{INTRODUCTION}

Cyanide has been used for fishing in many coastal waters of Indonesia as early as 1960s. This fishing practice has raised concern for its impacts on aquatic marine life. Despite regulations that declare cyanide fishing to be illegal since 1985 , the practice is still prevalent. The cyanide tablets used by fishers in Indonesia weigh about $20 \mathrm{~g}$ each. Fishers who are collecting ornamental fish for aquarium generally place one or two tablets of cyanide into a one-liter plastic squirt bottle filled with sea water, while food-fish collectors use three to five tablets (Rubec et al., 2001). Our study shows that common cyanide concentrations that are used by fishers ranging from 1.5 to $120 \mathrm{~g} 1^{-1}$.
In commercial market, cyanide comes in two distinct forms, sodium cyanide $(\mathrm{NaCN})$ and potassium cyanide (KCN). Both substances, usually referred to as 'potas', are potent toxin to fish and coral communities. Given the variability of application, differing wave action or currents, and differing length of stay in the vicinity of a cloud of cyanide solution, the stunning capacity of $\mathrm{NaCN}$ and KCN to fish may not differ significantly (McAllister et al., 2001). Once in the marine environment, cyanide can be found in various forms, such as cyanide ion $\left(\mathrm{CN}^{-}\right)$, alkali metal cyanides (i.e. $\mathrm{KCN}, \mathrm{NaCN}$ ), relatively stable metallocyanide complexes \{i.e. copper cyanide) or easily decomposable metallocyanide complexes [i.e. $\mathrm{Zn}(\mathrm{CN})_{2}$ ] (AMEQC-WG, 1998). 
Cyanide fishing has been demonstrated to kill corals and to contribute to high delayed mortality of marine aquarium fish. Moreover, Cervino et al. (2003) demonstrated that sodium cyanide at concentration of $50 \mathrm{mg} 1^{-1}$ of cyanide ion for one to two minute exposures caused mortality to corals (Acropora millepora, Goniopora sp., Favites abdita) and anemones (Aiptasia pallida). Cyanides are extremely toxic to fish, but about $50 \%$ of the fish survive the initial exposure if rapidly moved to clean water (Rubec, 1986). Concentrations greater than $5 \mathrm{mg} 1^{-1}$ are lethal under exposure time exceeding several minutes.

AMEQC-WG (1998) recommended that interim water quality criterion for the protection of marine aquatic life for free cyanide in seawater is $7.0 \mu g 1^{-1}$. This concentration in marine waters is intended to protect all forms of marine life and all aspect of the marine life-cycle in the ASEAN region. However, the AMEQC-WG (1998) also states that there is still data gap on the acute and chronic effect of cyanide to tropical fish and invertebrates. Hence, the present study tries to fill the data gap on toxicity of cyanide $(\mathrm{KCN})$ on ornamental coral fish, Chromis viridis.

\section{MATERIALS AND METHODS}

Ornamental coral fish, (Chromis viridis Cuvier), were obtained from commercial supplier. The fish were acclimatized to laboratory conditions and fed natural food (mysid shrimp) for at least two weeks before they were used in any experiment. They were not fed 24 hours prior to and during the tests. During acclimation period, fish mortality was maintained not to exceed $10 \%$, otherwise the fish batch was discarded.

A $1000 \mathrm{mg}^{-1}$ potassium cyanide stock solution (KCN) was prepared according to method 4500-CN-E-3b, (APHA, 1992). Test solutions were prepared from intermediate stock solution of $100 \mathrm{mg}^{-1} \mathrm{CN}^{-}$. A 10,000 $\mathrm{mg}^{-1}$ stock solution of cadmium was prepared by dissolving $17.909 \mathrm{~g}$ of cadmium chloride $\left(\mathrm{CdCl}_{2} \cdot \mathrm{H}_{2} \mathrm{O}\right.$ EMERCK, Art. 2011) in $1000 \mathrm{ml}$ of distilled water. A series of test Concentrations were prepared by diluting an appropriate amount of stock solution.

\section{Dosing concentrations of exposure}

Static-renewal toxicity tests were conducted according to the ASTM (1992) procedures with some modifications. The tests were conducted in three replicates. Renewal of seawater was conducted every 24 hours, based on previous study that free cyanide and total cyanide were lost from test solution during a 96-h exposure period (Otico et al., 1999). The tests were conducted in 401 glass aquaria filled with 201 of seawater and immersed in a running water system. The glass aquaria were fitted with flexi-glass lids. A range-finder test was performed to test the sensitivity of organisms at five concentrations, each differing by a factor of 10: i.e. 0, 0.1, 1.0, 10.0, 100.0 and were run for 96 hours. The purpose of range-finder test was to determine the upper and lower limits of cyanide concentrations needed in performing the definitive toxicity test.

Definitive tests were performed based on the result of the range-finder test. The nominal test concentrations were consecutively 10,18,32,56, and $100 \mu \mathrm{g} 1^{-1} \mathrm{CN}^{-}$. As a reference test, cadmium solutions were used at concentrations of 3.2, 5.6, $10.0,18.0$, and $32 \mathrm{mg}^{-1}$. Ten fish were randomly picked and subjected to each of the treatment concentration and control. Observation offish mortality, temperature, dissolved oxygen and $\mathrm{pH}$ was made daily. Dead fish was removed immediately from the test solution. All tests were completed in 96 hours to determine the $\mathrm{LC}_{50}$.

\section{Water conditions for exposure tanks}

Temperature and salinity of the test were maintained under marine tropical condition. Water quality was monitored daily and kept within the following ranges: water temperature $26-29^{\circ} \mathrm{C}$, $\mathrm{pH} 7.5$ - 8.5, dissolved oxygen 1.52 - $5.83 \mathrm{mg}$ $1^{-1}$, and salinity 33 - 37 psu. Lighting was based on natural condition that was approximately between $12 \mathrm{~h}$ light and $12 \mathrm{~h}$ dark.

\section{Statistical test}

The 96-h median lethal concentration (96-h $\mathrm{LC}_{50}$ ) of cyanide and cadmium with their $95 \%$ confidence limits were calculated based on 
nominal cadmium concentrations by Trimmed Spearman-Karber method.

\section{RESULTS}

A summary of seawater parameters and experimental condition during cyanide toxicity test is provided in Table 1 . Water temperature and $\mathrm{pH}$ were in natural range, $26.0-28.8^{\circ} \mathrm{C}$ and 7.89 - 8.39, respectively. Salinity and dissolved oxygen (DO) were 33 - 37 psu and 1.52 - 5.83 mg $1^{-1}$, respectively. Fish mortality during acclimation ranged between 2 and 5 percents.

The first replicate was terminated after 24 hours experiment because of high mortality rate on both control and treatment tanks. The second and third tests were considered valid as mortality in the controls was below $10 \%$. An average mortality after 96 hour exposure of cyanide (96h LC ${ }_{50}$ ) is shown in Figure 1. Significant mortality was observed in the cyanide treatment at concentrations of 56 and $100 \mu g 1^{-1}$.

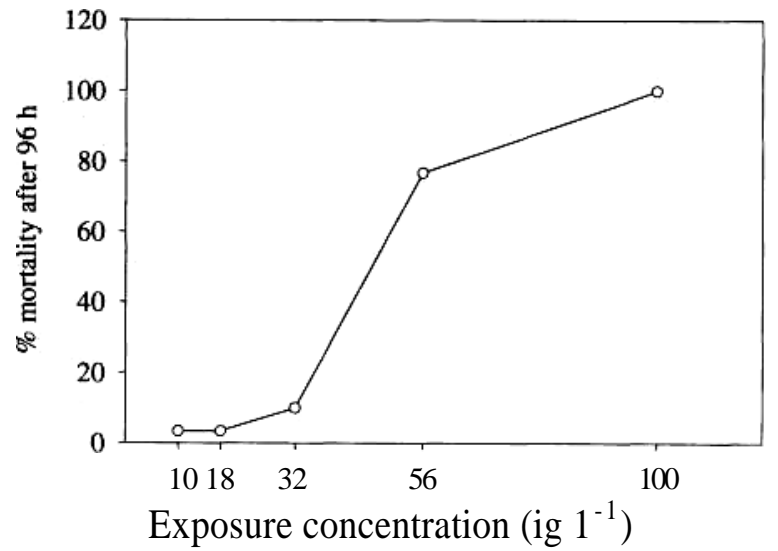

Figure 1. Relationship between mortality after $96 \mathrm{~h}(\%)$ and exposure concentration of cyanide (ig $1^{-1}$ )

An estimated 96-h $\mathrm{LC}_{50}$ value of cyanide to Chromis viridis is presented in Table 2. The $\mathrm{LC}_{50}$ values of cyanide ranged between 37.07 and $45.52 \mu \mathrm{g} 1^{-1}$ with an average of $41.30 \mu \mathrm{g} 1^{-1}$. This concentration indicated that cyanide substance was about 300 times more toxic to Chromis viridis than was the trace metal cadmium (reference test).

Table 1. Water quality parameters and loading density of fish during experiment

\begin{tabular}{|c|c|c|c|c|c|c|}
\hline \multirow[t]{2}{*}{ Parameter } & \multicolumn{3}{|c|}{$\begin{array}{l}\text { Treatment test } \\
\text { Cyanide }\end{array}$} & \multicolumn{3}{|c|}{$\begin{array}{c}\text { Reference test } \\
\text { Cadmium }\end{array}$} \\
\hline & $1^{\mathrm{st}}$ & $2^{\text {nd }}$ & $3^{\text {rd }}$ rep. & $1^{\mathrm{st}}$ & $2^{\text {nd }}$ & $3^{\text {rd }}$ rey \\
\hline Water temp. $\left({ }^{\circ} \mathrm{C}\right)$ & - & $26.9-28.5$ & $26.0-28.8$ & - & $26.5-28.0$ & $26.5-28.5$ \\
\hline $\mathrm{pH}$ & - & $7.89-8.39$ & $7.91-8.28$ & - & $7.50-8.30$ & $7.75-8.27$ \\
\hline $\mathrm{DO}\left(\mathrm{mg} \mathrm{l}^{-1}\right)$ & - & $2.01-5.83$ & $1.52-4.66$ & - & $3.00-5.50$ & $2.00-4.50$ \\
\hline Salinity (psu) & - & $33-34$ & $33-37$ & - & $33-35$ & $34-36$ \\
\hline Aeration & - & No & No & - & No & No \\
\hline $\mathrm{L}: \mathrm{D}(\mathrm{h})$ & - & $12: 12$ & $12: 12$ & - & $12: 12$ & $12: 12$ \\
\hline No. of fish (ind.)/vol (l) & - & $10 / 20$ & $10 / 20$ & - & $10 / 20$ & $10 / 20$ \\
\hline Wet weight (g) & - & 1.86 & 1.92 & - & 1.86 & 1.92 \\
\hline Loading density $\left(\mathrm{mg} \mathrm{l}^{-1}\right)$ & - & 93 & 96 & - & 93 & 96 \\
\hline
\end{tabular}

Note: $1^{\text {st }}$ replicate was discarded, as most of the fish were dead.

Table 2. Median lethal concentration $\left(\mathrm{LC}_{50}\right)$ of cyanide and reference test of cadmium $(\mathrm{Cd})$ to ornamental coral fish (Chromis viridis) after 96-h exposure.

\begin{tabular}{|c|c|c|c|c|c|c|}
\hline \multirow{2}{*}{ Test } & \multicolumn{3}{|c|}{ Cyanide $\left(\mu \mathrm{g} \mathrm{I}^{-1}\right)$} & \multicolumn{3}{c|}{ Cadmium $\left.^{\mathrm{m}} \mathrm{mg} \mathrm{l}^{-1}\right)$} \\
\cline { 2 - 7 } & $\mathrm{LC}_{50}$ & LOEC $^{\mathrm{a}}$ & NOEC $^{\mathrm{a}}$ & $\mathrm{LC}_{50}$ & LOEC $^{\mathrm{a}}$ & NOEC $^{\mathrm{a}}$ \\
\hline 1 & $\mathrm{~b}$ & - & - & & - & - \\
\hline 2 & 45.52 & 56 & 32 & 11.07 & 3.2 & $<3.2$ \\
\hline 3 & 37.07 & 56 & 32 & 15.60 & 3.2 & $<3.2$ \\
\hline
\end{tabular}

Note: aLOEC - Low Observable Effect Concentrations, NOEC - No Observable Effect Concentrations. 'Test was terminated at $24 \mathrm{~h}$ of exposure because of high mortality 
Low and no-effects observed concentrations (LOEC and NOEC) of cyanide and cadmium were calculated based on nominal chemicals concentration. LOEC and NOEC values of cyanide for Chromis viridis were $56 \mu \mathrm{g} 1^{-1}$ and $32 \mu \mathrm{g} 1^{-1}$, respectively. While LOEC and NOEC values of cadmium for the fish were 3.2 $\mathrm{mg} 1^{-1}$ and $<3.2 \mathrm{mg} 1^{-1}$, respectively.

\section{DISCUSSION}

Cyanide is known to impair enzyme systems that facilitate oxygen metabolism \{e.g. cytochrome oxydase) and other physiological functions in fish and invertebrates, and to damage the liver, spleen, heart and brain of the fish (Dampster and Donalson, 1974). Early research found that cyanide to be acutely toxic at concentration greater than $100-300 \mu \mathrm{g} 1^{-1}$ causing death within 96 h (Doudoroff, 1980 in Rubec, 1986). Chronic toxicity also occurs when fish exposed to cyanide do not die within $96 \mathrm{~h}$, but suffers stress which leads to their subsequent death. Prolonged exposure to low concentrations of hydrocyanic acid, HCN, (5 -10 $\mu \mathrm{g} 1^{-1}$ ) causes adverse effects on fish egg, fry and adult fish, including reduction of hatching success and survival, reduction of growth, impairment of swimming performance, and inhibition of reproduction (Rubec, 1986). Rubec (1986) also stated that many of the above effects can be traced to the fact that cyanide interferes with oxygen metabolism by blocking key enzyme systems such as cytochrom oxydase, reduces the capacity of hemoglobin to carry oxygen in the blood and blocks enzymatic pathways in the liver.

Present study shows that when KCN is dissolved in water, it dissociates to HCN that is rapidly taken up by the fish. Within a few hours after exposure, an enzyme called thodanase (thiosulfate sulfur transferase) converts the HCN to thyocyanate $\left(\mathrm{SCN}^{-}\right)$. Fish exposed to $\mathrm{SCN}^{-}$ shows sign of convulsion, gasping, loss of equilibrium and buoyancy, flaring of the opercula, and within minutes, cessation of ventilation and extreme rigor.

Few Studies have been done on the effect of cyanide on coral fish both in Indonesian and in
Southeast Asian regions. First study on marine fish confirmed that cyanide was very harmful to milkfish, Chanos chanos (Otico et al., 1999). The present study was the first attempt to fill a gap on toxicity of cyanide to ornamental coral fish in Indonesia. Under static renewal toxicity test, cyanide was very toxic to Chromis viridis with $\mathrm{LC}_{50}$ (at $96 \mathrm{~h}$ ) of $41.3 \mu \mathrm{g}$ $1^{-1}$. This cyanide concentration was 300 times more toxic to Chromis viridis than that reference test, Cd (96-h LC $\mathrm{C}_{50}$ of Cd, $13.3 \mathrm{mg}^{-1}$ ). Compared to previous study (Otico et al., 1999), juvenile of Chromis viridis was more sensitive to cyanide than the milkfish fry (Chanos chanos). The 96-h LC $\mathrm{L}_{50}$ of cyanide for milkfish fry $(1.0-1.5 \mathrm{~cm}, 0.01-0.02 \mathrm{~g}$ wet weight) was $0.53 \mathrm{mg} 1^{-1}$.

From the above studies it was apparent that estuarine and coral fish had different sensitivity to cyanide contamination. The study also supports general hypothesis that toxicity of cyanide differs for different fish sizes, ages and species. This evidence also indicated that using non-local or non-endemic species to develop water quality criteria for cyanide and other toxic substances should be done cautiously.

Our sample of fish (Chromis viridis) was obtained from a commercial aquarium distributor. It was assumed that the fish was caught using environmentally friendly method. If this were true then the fish would be really sensitive to cyanide. In contrast, if the fish have had experience exposure to cyanide, then the fish might be more sensitive to cyanide. As Sprague (1985) stated that acclimation at one-third of the lethal level of cyanide, the fish became more sensitive by about $30 \%$ in the first week. With continued acclimation, their tolerance climbed back to the original level by the end of 3 weeks.

It was estimated that LOEC and NOEC of cyanides to C. viridis were at concentration of $56.0 \mu \mathrm{g} 1^{-1}$ and $32.0 \mu \mathrm{g} 1^{-1}$, respectively. The lowest observable effect concentration (LOEC) value of cyanide for Chromis viridis (32.0 $\mu \mathrm{g} 1^{-1}$ ) indicates that the fish was very sensitive to cyanide contamination. For comparison, toxicity of cyanide to tropical marine fishes and invertebrates is presented in Table 3. Among the fishes that have been studied, C. viridis is very sensitive to 


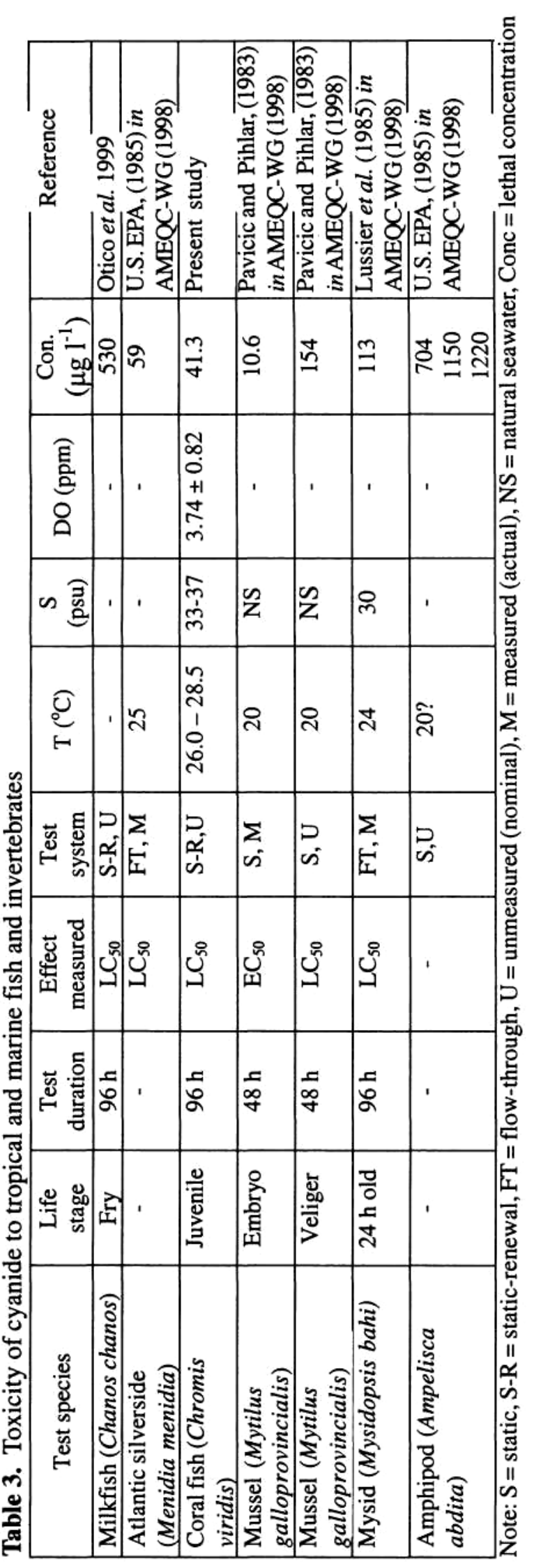

cyanide. The most sensitive among studied organisms is the larvae of blue mussel (Mytilus galloprovincialis). Further studies are needed to understand the response of fish during toxicity experiment. Aspects to be studied include feeding behavior (cannibalism), biochemical response to cyanide, and technical aspects involved in toxicity test using flow-through system in order to mimic natural condition.

Acknowledgments. This research was funded by Coral Reef Rehabilitation and Management Program (COREMAP). We are grateful to Dr. Suharsono who allows us to participate in the cyanide project. We also would like to thank Ms. Lily Panggabean, Purwanto, Triyoni and Eston Matondang for their assistance during the experiment. We wish to thank CV Dinar Jakarta, especially Mr. Dody T. Wahyu and his staff for facilitating us with their lab in conducting the experiment.

\section{REFERENCES}

AMEQC-WG. 1998. ASEAN Marine Environmental Quality Criteria (AMEQC) for cyanide. Draft No. 3. ASEAN-Canada Marine Science Program; 30pp.

APHA. 1992. Standard method for the examination of water and wastewater. $19^{\text {th }}$ edition. APHA, AWWA, WEF. Washington DC. $4-26$

ASTM. 1992. Annual book of American Society for Testing and Materials (ASTM) standard: Water and environmental technology. Vol. 11.04. Philadelphia, PA. USA; 1426 pp.

Cervino, J.M., R.L. Hayes, M. Honovich, T.J. Goreau, S. Jones and PJ. Rubec. 2003. Changes in zooxanthellae density, morphology, and mitotic index in hermatypic corals and anemones exposed to cyanides. Mar. Poll. Bull, 46:573-586.

Dampster, R.P. and M.S. Donalson. 1974. Cyanide-tranquilizer or poison. Aquarium Digest International Tentra, 2(4): 21-22.

McAllister, D.E., N.L. Caho and C.T. Shih. 2001. Cyanide fisheries: where did they start? SPC Live Reef Fish Information Bulletin; 6 pp. 
Otico, P.F.J., E.S. Deocadiz, J.P. Tagasa and J.B. Ty. 1999. Acute toxicity test for cyanides using milkfish (Chanos chanos) fry. In: I, Watson., G Vigers, K.S. Ong, C. McPherson, N. Milson, A. Tang and D. Gass (eds.) ASEAN marine environmental management: Towards sustainable development and integrated management of the marine environment in ASEAN. Proceedings of the Fourth ASEANCanada Technical Conference on Marine Science (26-30 Oct. 1998). Langkawi Malaysia: 77-85.

Rubec, P.J., F. Cruz, V. Pratt, R. Oellers and F. Lallo. 2001. Cyanide-free, net-caught fish for the marine aquarium trade. Aquarium Sciences and Conservation, 3:37-51.
Rubec, P.J. 1986. The effect of sodium cyanide on coral reefs and marine fish in the Philippines. In: J.L. Maclean, L.B. Dizon and L.V. Hosillos (eds.) The First Asian Fisheries Forum, Asian Fisheries Society, Manila, Philippines: 291-302.

Smith, R.P. 1991. Toxic response of the blood. In: M.O. Amdur, J. Doull, CD Klassen (eds.). Toxicology: the basic sciences of poisons. McGraw-Hill, Inc, USA: 276-279.

Sprague, J.B. 1985. Factors that modify toxicity blood. In: M.O. Amdur, J. Doull, C.D. Klassen (eds.). Toxicology: the basic sciences of poisons. Me Graw-Hill, Inc. USA: 124-163. 